\title{
Araç Kullanırken Müzik Dinlemek, Sürücü Dürtüselliği, Trafik Ortamının Risk Seviyesi ile Sürücü Davranışları ve Risk Algısı Arasındaki İlişki
}

\author{
Ceren Ersöz $^{1 *}$ (D), Nesrin Budak ${ }^{1}$ (D), İbrahim Öztürk ${ }^{1,2}$ (D), Bahar Öz ${ }^{1}$ (D) \\ ${ }^{1}$ Güvenlik Araştırma Birimi, Psikoloji Bölümü, Orta Doğu Teknik Üniversitesi, Ankara Türkiye. \\ ${ }^{2}$ Psikoloji Bölümü, Çanakkale Onsekiz Mart Üniversitesi, Çanakkale Türkiye.
}

Öz

Müzik dinlemek, çoğu yol kullanıcısının sergilediği davranışlardan biridir. Ayrıca, dürtüsellik gibi insan faktörü ile ilgili değişkenler ve trafik ortamını etkileyen fiziksel faktörler sürücülerin riskli sürücü davranışlarını etkilemektedir. Bu çalışma kapsamında, araç kullanırken müzik dinlemek, sürücü dürtüselliği ve trafik ortamının risk seviyesi ile sürücülerin risk algısı ve davranışları arasındaki ilişki araştııılmaktadır. Bu doğrultuda, 50 sürücüden (37 erkek, 13 kadın) veri toplanmıştır. Katılımcılar, çalışma öncesinde, sürüşs sırasında müzik dinleyecekleri deney grubu ve kontrol grubu olmak üzere iki gruba rasgele atanmıştır. Katılımcılar iki farklı (düşük ve yüksek riskli) simülasyon senaryosu, demografik bilgi formu, sürüş senaryolarına ilişkin risk algısı sorusu ve Dürtüsel Sürücü Ölçeği'nden oluşan bataryayı tamamlamıştır. Müzik dinlemenin sürüş simülatöründeki sürücü davranışları için bir etkisi olmazken, işlevsiz dürtüselliğin, farklı risk seviyesine sahip iki trafik ortamında da sürücü davranışı ile anlamlı bir iliş̧kiye sahip olduğu bulunmuştur. Yüksek işlevsiz dürtüselliğe sahip bireyler, yüksek ve düşük riskli senaryolarda daha hızlı araç kullanmış ve yüksek riskli senaryoda hızlarını daha fazla değiştirmiş, șeridin daha solunda araç kullanmış ve bulunduğu șeridi daha fazla değiştirmiş̧tir. Bulgular, işlevsiz dürtüselliğin farklı trafik ortamlarında sürücü davranışlarını etkileyen faktörlerden biri olduğunu ve yol güvenliği açısından daha fazla araştırma yapılması gerekliliğini sunmaktadır.

Anahtar Kelimeler: müzik, dürtüsel sürücülük, risk seviyesi, risk algısı, sürücü davranışları

\section{The Relationship between Listening to Music While Driving, Driver Impulsivity, Risk Level of the Road, and Behaviors and Risk Perception of Drivers}

\begin{abstract}
Listening to music is one of the behaviors that most road users exhibit. Moreover, factors like impulsivity as variables affecting human factors and physical factors affecting traffic environment influence risky behaviors of driver. Within the scope of the present study, the effects of listening to music while driving, driver impulsivity and the risk level of traffic environment on risk perception and driver behaviors were investigated. Data were collected from 50 drivers (37 males, 13 females). Participants were randomly assigned to two groups before the study, one with experimental condition and one with control condition. Participants completed a battery consisting of two different (low and high risk) simulation scenarios, the demographic information form, the risk perception question, and the Impulsive Driver Scale. Unlike music, dysfunctional impulsivity had a significant relationship with driver behaviors in two traffic environments with different risk levels. Individuals with high dysfunctional impulsivity showed higher speed in high-risk and low-risk scenarios and showed higher speed variance, used the vehicle to the left of the lane, and showed more lane deviation in high-risk scenarios. Findings showed that dysfunctional impulsivity is one of the factors affecting driver behaviors in different traffic environments and needed to be investigated more with respect to road safety.
\end{abstract}

Keywords: music, impulsive driving, risk level, risk perception, driver behaviors

\footnotetext{
* İletişim / Contact: Ceren Ersöz, Güvenlik Araştırma Birimi, Psikoloji Bölümü, Orta Doğu Teknik Üniversitesi, Ankara Türkiye.E-Posta /Email: ceren.ersoz@metu.edu.tr. Gönderildiği tarihi / Date submitted: 18.01.2019, Kabul edildiği tarih / Date accepted: 16.04.2019

Alıntı / Citation: Ersöz C., Budak N., Öztürk İ. ve Öz B. (2019). Araç kullanırken müzik dinlemek, sürücü dürtüselliği, trafik ortamının risk seviyesi ile sürücü davranışları ve risk algısı arasındaki ilişki. Trafik ve Ulaşım Araştırmaları Dergisi, 2(1), $30-50$.
}






\section{Araç Kullanırken Müzik Dinlemek, Sürücü Dürtüselliği, Trafik Ortamının Risk Seviyesi ile Sürücü Davranışları ve Risk Algısı Arasındaki İlişki}

\subsection{Risk Algısı}

Yol güvenliği çıktılarını ve trafik ortamındaki davranışları etkileyen faktörlerden biri de risk algısıdır (Kanellaidis, Zervas ve Karagioules, 2000). Sürücülerin risk algısı yol güvenliği ile ilgili tutumlar üzerinde doğrudan bir etkiye sahiptir (Ram ve Chand, 2016). Bireyler farkl1 durumlarda riskleri farklı şekillerde değerlendirebilirler. Sürücülerin sahip olduğu risk algısının yüksek veya düşük olması, trafik ortamında tehlikeli durumlardan elde edilen bilgiler ve bireyin potansiyel kazaları önleme kabiliyeti ile ilişkilidir (Brown ve Groeger, 1988). Jonah (1986) risk algısını bir olayın meydana gelme olasılığının algılanması olarak tanımlamıştır. Ayrıca risk algısı, risk alan yazınında birey tarafından algılanan risk düzeyinin belirlenmesi olarak tanımlanmıştır (HaSPA, 2012). Lund ve Rundmo (2009) tarafindan yapılan araştırma, trafikteki güvenliğin trafik ortamında riskli durumları değerlendirme yeteneğinden etkilendiğini ortaya koymuştur. Aynı çalışma, trafikte riskleri fark etme konusunda iyi olmayan sürücülerin, trafik ortamında riskleri fark etme konusunda iyi olan sürücülerden daha fazla trafik kazası geçirdiğini göstermiştir.

Riskli sürücü davranışları ile risk algısı arasında negatif bir ilişki bulunmaktadır (Cohn, Macfarlane ve Yanez, 1995; Ponnaluri, 2011). Trafik ortamında riski düşük algılayan sürücüler riskli sürücü davranışları göstermeye daha eğilimlidir. Risk algısı seviyesinin sürücünün deneyim düzeyi ile arttı̆̆ belirtilmiştir (Deery, 1999). Genç sürücülerin bir kaza deneyimleme riskini hafife aldıkları ve sürüş becerilerini olduğundan fazla gösterdikleri, bunun sonucunda ise trafikte daha fazla risk aldıkları ve trafik kazalarına deneyimli olan sürücülerden daha fazla maruz kaldıkları bulunmuştur. Ayrıca, genç sürücülerin risk algısındaki düşüşle birlikte gösterdikleri riskli sürücü davranışlarının arttığı tespit edilmiştir. Buna ek olarak genç sürücüler, deneyimli sürücülere göre, risk almaya ve bir kazaya dâhil olmaya daha eğilimlidir (Machin ve Sankey, 2008).

Ulleberg ve Rundmo (2003), riskli sürücü davranışlarının ve risk alma konusundaki tutumların risk algısı seviyesi ile ilişkili olduğunu belirtmiştir. Genç sürücülerin yüksek risk algısına sahip olduğu; kural ihlali, hız yapma ve diğer aracı yakından takip etme gibi risk alma davranışları göstermeye daha az eğilimli olduğu bulunmuştur. Havârneanu ve Havârneanu (2012) risk algısı ve hız sınırını ihlal etme eğilimine ilişkin çalışmasında risk algısı ve hız sınırı ihlali arasında negatif bir ilişki raporlamıştır. Risk algısı düşük sürücüler, hız sınırlarını ihlal etmeye daha eğilimli görülmektedir. Ayrıca, sürücülerde risk algısı arttıkça, öndeki aracı takip mesafesi artmaktadır (Harbeck ve Glendon, 2013).

Sürücüler trafikteki durumları olduğundan daha riskli algıladığında, trafik ortamında daha güvenli davranışlar gösterme eğilimindedir (Ngueutsa ve Kouabenan, 2017). Ram ve Chand (2016) tarafından yürütülen bir diğer çalışma, risk algısı ile sürücülerin sorumluluk ve dikkat gibi yol güvenliğine yönelik daha olumlu tutumlar sergilemelerine yol açan yoldaki hız değerlendirmesi gibi sürüş görevlerinin algılanması arasında pozitif bir ilişki olduğunu ortaya koymuştur. Sürücülerin risk algısı düzeyindeki artışla birlikte olası kazalar için önleyici davranışlar gösterme eğilimi artmaktadır. Buna ek olarak, sürücüler saldırganlık, dikkatsizlik, sürüş dışındaki faaliyetler ve daha fazla sorumluluk almaktan kaçındıkları ve trafik kurallarına daha fazla uyma davranışı göstermektedirler.

Yukarıda bahsi geçen çalışmalarda risk algısının, yol güvenliği ve yol güvenliği çıktıları üzerindeki etkisi incelenmiştir. Bunun yanı sıra, risk algısı bir çıktı olarak da ele alınabilmektedir ve risk algısını etkileyen bazı faktörle alan yazında mevcuttur. Sürüş sırasında sürücülerin risk algısı, psikofiziksel durum (de Oña, de Oña, Eboli, Forciniti ve

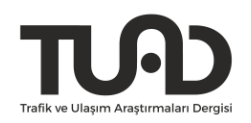


Mazzulla, 2014) gibi bazı bireysel faktörlerden etkilenmektedir. Örneğin, bir kişilik özelliği olarak ele alınan dürtüsellik ile risk algısı, alan yazında birbiriyle ilişkili iki değişken olarak yer almakta ve aralarında pozitif bir ilişki bulunmaktadır (Ryb, Dischinger, Kufera ve Read, 2006).

Her geçen gün ilerleyen teknoloji, sürücüleri araç kullanırken etkileyen birçok çevresel faktör (sesli navigasyon sistemleri, radyo ve diğer ses sistemleri gibi) doğurmaktadır. Günümüzde, çoğu sürücü sürüş sırasında başka görevleri de (yemek yemek, radyo kanalı seçmek, telefonla konuşmak gibi) yerine getirmektedir. $\mathrm{Bu}$ tarz çevresel faktörlerin, sürücülerin sürüş sırasındaki risk algısına olan etkisi ise alan yazında pek yer bulmamıştır. Buna rağmen, araç kullanırken müzik dinlemek alan yazında işitsel bir dikkat dağıtıcı olarak incelenmektedir ve dikkat dağıtıcılar ile risk algısı arasındaki bağlantıyı inceleyen bazı çalışmalar mevcuttur. Titchener, White ve Kaye (2009), fiziksel dikkat dağıtıcılar (yemek yemek, aracın navigasyon sistemini kullanarak rota belirlemek, radyodan bir şarkı seçmek, vb.), işitsel dikkat dağıtıcılar (müzik dinlemek, telefonda biriyle konuşmak, vb.) ve risk algısı arasındaki ilişkiyi araştırmıştır. Her dikkat dağıtıcı, katılımcılar tarafından ne kadar riskli algılandığına ve ne kadar maruz kalındığına dair değerlendirilmiştir. Katılımcılar, on dokuz dikkat dağıtıcı arasından sürüş sırasında müzik dinlemeyi en az riskli dikkat dağıtıcı olarak değerlendirmiştir. Bunun yanı sıra, sürüş sırasında müzik dinlemenin, katılımcıların günlük hayatta en çok maruz kaldıkları dikkat dağıtıcı olduğu ortaya konmuştur. (Titchener ve ark., 2009).

\subsection{Araç Kullanırken Müzik Dinlemek}

Müzik yaşamımızın farklı ortamlarında karşımıza çıkabilen bir unsur olmakla birlikte, araçlarda araç içi ekipmanlar sayesinde sürücülerin ve yolcuların kullanımına sunulmaktadır. Son on beş yılda en popüler işitsel uyaranlardan biri olan araç kullanırken müzik dinlemek, başlangıçta çoğunlukla bir dikkat dağıtıcı olarak ele alınmıştır (Brodsky ve Slor, 2013; Ünal, Steg ve Epstude, 2012). Araç kullanırken müzik dinlemek çoğunlukla ikincil bir görev olarak ele alınmış; müzik dinlemenin sürücü performansına olan etkisi, gerçek zamanlı araç kullanma (Brodsky ve Slor, 2013), simülasyon (Brodsky, 2001; Febriandirza, Chaozhong, Zhong, Hu ve Zhang, 2017; Hughes, Rudin-Brown ve Young, 2013; Ünal, de Waard, Epstude ve Steg, 2013; van der Zwaag ve ark., 2012) ve oyun çalışmaları (Cassidy ve MacDonald, 2010; North ve Hargreaves, 1999) ile incelenmiş; zihinsel çaba (Ünal ve ark., 2012), görev zorluğu (Wang, Jimison, Richard ve Chuan, 2015) ve araç kontrolü (Brodsky, 2001) gibi farklı değişkenler ile birlikte araştırılmıştır. Sürücülük ve araç kullanırken müzik dinlemek ile ilgili alan yazının sunduğu genel çerçeve, araç kullanırken müzik dinleyen sürücülerin daha yavaş araç kullandığını (Hughes ve ark., 2013) ve daha fazla trafik ihlalinde bulunduklarını ortaya koymaktadır (Brodsky, 2001).

Öte yandan, araç kullanırken müzik dinlemenin, sürücülük için her zaman bir dikkat dağıtıcı unsur olmadığını gösteren çalışmalar da mevcuttur. Ferdinand ve Menachemi (2014) tarafindan, araç kullanırken gerçekleştirilen ikincil görevler ve bu görevlerin güvenlikle ilişkilerine dair sistematik bir inceleme yapılmıştır. Bu incelemede, araç kullanırken müzik dinlemenin güvenli olmadığını raporlayan çalışmaların oranı $\% 8$ olarak belirlenmiştir. Ayrıca, sürüş sırasında müzik dinlemenin sürüş performansını bozmadığı (Ünal ve ark., 2012) ve hatta artan uyarılma ile monoton trafik ortamındaki sürüş performansını geliştirdiği ortaya konmuştur (Ünal ve ark., 2013).

Müzik, alan yazında tempo (Brodsky, 2001), aşinalık (Jimison, 2014), ses şiddeti (Beh ve Hirst, 1999), tercih (Wiesenthal, Hennessy ve Totten, 2000) ve janr (Dibben ve Williamson, 2007) olmak üzere farklı çeşitlerde çalışılmıştır. Müziğin trafik ortamındaki değişkenlerle ilişkisi incelendiğinde, müzik temposu ile hız, algılanan hız ve trafik ihlalleri arasında pozitif

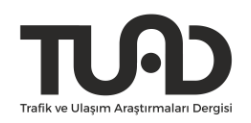


bir ilişki olduğu; sürücülerin araç kullanırken dinledikleri müziğin temposu hızlandıkça, sürüş hızlarının, algıladıkları sürüş hızının, kırmızı 1şık ihlalinin ve çarpışmaların arttığı ortaya konmuştur (Brodsky, 2001). Buna ek olarak, araç kullanırken bildikleri müziği dinleyen sürücülerin hız sınırını daha fazla aştıkları (Jimison, 2014), araç kullanırken yüksek sesle müzik dinlemenin sürüş performansını azalttığı (Beh ve Hirst, 1999) ve araç kullanırken tercih edilen müziği dinlemenin ise stresi azalttığı (Wiesenthal ve ark., 2000) bulunmuştur.

Öte yandan, sürücü davranışları, araç kullanırken dinlenilen müziğin türüne göre anlamlı bir değişiklik göstermemektedir (Santoso, Maulina, Adystia ve Oei, 2013). Müziğin dikkat dağıtıcı yönünü inceleyen Brodsky ve Slor (2013), araç kullanırken tercih edilen müziği dinlemenin acemi sürücüler için trafik güvenliği adına bir risk teşkil ettiğini ortaya koymuştur. Araç kullanırken tercih ettikleri müziği dinleyen acemi sürücüler, alternatif müzik dinleyen acemi sürücüler ile karşılaştırıldığında, trafikte daha fazla hataya dayalı yetersiz sürücü davranışı sergiledikleri bulunmuştur. Buna ek olarak, araç kullanırken tercih edilen müziğin dinlenmesinin acemi sürücüler için daha fazla memnuniyet verdiği de belirtilmiştir (Brodsky ve Slor, 2013). Aynı çalışmada ayrıca sürücülerin alternatif müzik dinledikleri durumda algılanan sürücü dikkati ve dürtüsellik-heyecan arama özellikleri arasında negatif ilişki olduğu raporlanmıştır. Alan yazında yer alan bulgular, müziğin trafik ortamına farklı şekillerde etkisinin olabileceğini göstermektedir.

Araç kullanırken müzik dinlemek, ikincil bir görev olarak ele alındığında, aynı anda araç kullanmak ve müzik dinlemek çoklu görev olarak adlandırılmaktadır. Çoklu görev ve dürtüsellik arasındaki ilişkiyi inceleyen bir araştırma, yüksek dürtüselliğe sahip bireylerin düşük dürtüselliğe sahip bireylere göre daha iyi çoklu görev sergilediklerini ortaya koymuştur (Sanbonmatsu ve ark., 2013). Bu çalışmanın yanı sıra, dürtüsellik gibi başlıca bireysel etkenlerin vurgulandığı başka bir araştırmada, araç kullanırken müzik dinlemenin acemi sürücüler üzerindeki etkisi incelenmiştir. Yüksek dürtüselliğe sahip acemi sürücülerin araba kullanırken alternatif müziğe kıyasla, kendi seçtikleri müziği dinlerken daha fazla keyif aldıkları bulunmuştur. Buna ek olarak, düşük dürtüselliğe sahip acemi sürücülerin ise hem kendi seçtikleri müziği hem de alternatif müziği dinlerken trafik ortamında daha dikkatli araç kullandıkları ortaya konmuştur (Brodsky ve Slor, 2013).

\subsection{Dürtüsellik}

Dürtüsellik, alan yazında birçok farklı bakış açışı temel alınarak incelenmektedir. Duygu, genetik, psikoloji, biyoloji ve sosyo-bilişsel gibi birçok temel olgu üzerinden incelenen bu kavram (Lassiter, 2009), alan yazında bilişsel, davranışsal ve karakterolojik olmak üzere üç farklı bakış açısına göre çalışılmıştır (Arce ve Santisteban, 2006). Dürtüsellik, ilk olarak davranış üzerinde kontrol olarak kavramsallaştırılmış (Barratt, 1972) ve daha sonra duyarlılık, etkinlik ve sosyallik ile birlikte mizaç modelinin dört faktöründen biri olarak kavramsallaştırılmış; önleyici kontrol, karar verme zamanı, devamlılık eksikliği ve can sikıntısı/heyecan arama olmak üzere dört yapı üzerine temellendirilmiştir (Buss ve Plomin, 1975). Dürtüsellik kavramı genel olarak ise, gösterilecek davranışın sonuçlarının üzerinde durmadan, bu sonuçları değerlendirmeden ve öngörmeden hareket etmek şeklinde tanımlanmaktadır (Caci, Nadalet, Baylé, Robert ve Boyer, 2003).

Bir kişilik özelliği olarak ele alınan dürtüsellik, Barratt (1985) tarafından incelenmiş ve motor, biliş ve plan yapma olarak üç yapıya ayrılmıştır. Whiteside ve Lynam (2001) alan yazındaki dürtüsellik kavram çeşitliliğini önlemek adına dört faktör modelini geliştirmişlerdir. $\mathrm{Bu}$ modele göre, dürtüselliği oluşturan faktörler (olumsuz) aciliyet, önceden planlama (eksikliği), sebat (eksikliği) ve heyecan arama olarak belirlenmiştir. Aciliyet, sıkıntılı veya olumsuz bir durumda düşünmeden davranmay1; önceden planlama, eyleme geçmeden önce

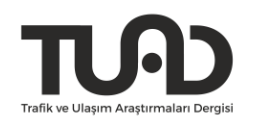


düşünmeyi ve planlamayı; sebat, bir görevi tamamlayana kadarki kararlılığı; heyecan arama ise, yeni deneyimlere açık olmayı ve heyecan arayışı içinde olmayı ifade etmektedir. Bu modele daha sonra, aciliyetin sadece olumsuz durumlarda ortaya çıkmayacağ olumlu bir durumda düşünmeden hareket etmek anlamına gelen olumlu aciliyet faktörü eklenmiştir (Cyders ve ark., 2007).

Dürtüsellik, yaygın olarak ergenlik ve genç erişkinlik dönemindeki bireylerde heyecan arama kavramı (Zimmermann, 2010) ile birlikte araştırılmış ve hormonal değişimler ile (Steinberg ve ark., 2008) ilişkilendirilmiştir. Bu iki değişken kavramsal olarak birbirine benzemelerine rağmen, kontrol ve istek yönünden farkl1lık göstermektedir (Dahlen, Martin, Ragan ve Kuhlman, 2005). Dürtüsellik, bireyin göstereceği davranışları üzerindeki kontrolüne işaret ederken (Barratt, 1972), heyecan arama ise bireyin yeni deneyimlere ve risk almaya yönelik isteğini ifade etmektedir (Zuckerman, 1994).

Dürtüsellik kavramının çeşitliliği, kavramın boyut tartışmasından kaynaklanmaktadır. $\mathrm{Bu}$ kavram alan yazına tek boyutlu olarak kazandırılırken, daha sonra çok boyutlu olarak tanımlanmıştır (Di Milia, 2013). Günümüzde de yaygın olarak çok boyutlu olarak incelenmekte ve çalışılmaktadır. Ayrıca, dürtüsellik, Dickman (1990) tarafından yapılan çalışma öncesinde sadece olumsuz bir kişilik özelliği olarak değerlendirilirken, Dickman, dürtüselliğin çok boyutlu bir kavram olduğunu ileri sürerek bu kavramı işlevsiz ve işlevsel dürtüsellik olarak ikiye ayırmıştır. İşlevsiz dürtüsellik, bireylerin davranışlarının sonuçlarını düşünmeden tedbirsiz bir şekilde hareket etmesi olarak tanımlanırken, işlevsel dürtüsellik ise, belirli durumlarda faydalı olabilecek şekilde ani kararlar vermek olarak tanımlanmıştır. Örneğin, Dickman (1990) tarafından geliştirilen dürtüsellik envanterinde, "Hemen bir şey yapmam gereken yoksa şansımı kaybedeceğim durumlarda, beklenmedik firsatlardan yararlanmakta iyiyim." işlevsel dürtüsellik maddesi olarak yer almaktayken, "Genellikle sonuçları düşünmeden bir şeyler söyler veya yaparım." maddesi ise işlevsiz dürtüsellik maddesi olarak yer almaktadır. Dürtüsellik envanteri için yapılan faktör analizi de dürtüselliğin iki ana faktör yapısı olduğunu göstermektedir.

Son yirmi yılda birçok çalışmada dürtüsellik ile riskli sürücü davranışları arasındaki ilişki araştırılmıştır. Dürtüsellik ve hızlı araç kullanma, emniyet kemeri kullanmama, alkol etkisi altında araç kullanma ve trafik kurallarının ihlali gibi sapkın sürücü davranışları arasında pozitif ilişki olduğu gözlenmiştir (Ryb ve ark., 2006). Trafikteki ihlaller ile paralel biçimde, başkalarına zarar verme niyetini içermeyen dalgınlık, ihmal ve hatalar ile dürtüsellik (Wickens, Toplak ve Wiesenthal, 2008) ve dürtüselliğin beş faktöründen olumlu aciliyet (Cyders ve ark., 2007) arasında pozitif ilişki raporlanmıştır. Yüksek dürtüselliğe sahip bireylerin aynı zamanda daha hızlı araç kullanan (O'Brien ve Gormley, 2013) ve sürüş sırasında telefon kullanan bireyler olduğu (Hayashi ve ark., 2017) ortaya konulmuştur. Ayrıca, dürtüselliğin beş faktörü ile riskli sürücü davranışları arasındaki ilişkiyi inceleyen bir çalışma ise, her faktörün son bir yılda dikkatsiz araç kullanma ile pozitif ilişkili olduğunu bildirmiştir (Luk ve ark., 2017). Yüksek dürtüselliğe sahip bireylerin araç kullanırken daha fazla saldırgan davranışlar sergilediği ve daha fazla öfkelendiği bulunmuştur (Smorti ve Guarnieri, 2016). Bunun yanı sıra, yüksek sürücü işlevsiz dürtüselliğe (SİZD) sahip bireyler daha fazla hafif ve aşırı saldırgan sürücü davranışları sergilediklerini bildirmişlerdir (Kovácsová ve ark., 2016). Özkan, Öztürk ve Öz (2018) tarafından yapılan bir çalışmada ise işlevsiz sürücü davranışları boyutlarından sürücü sıkışıklığı sürücü öfkesinin saldırgan ifade edilmesi ile pozitif ilişkiliyken uyum sağlayıcı/yapıcı ifadesi ile negatif ilişkilidir. Sürücü sıkışıklığı, Bıçaksız (2015) tarafından düşünmeden, anlık karar verme olarak tanımlanmıştır. Sürücü sıkışıklığı yüksek sürücüler trafikte öfkelerini daha saldırgan şekilde ifade etmeyi tercih etmektedir.

\section{TQD}


Dürtüsellik ve trafik güvenliği ile ilgili çalışmalar incelendiğinde dürtüsellik kavramının genel olarak bir kişilik özelliği şeklinde ele alındığı ve bağlamdan bağımsız olarak çalışıldığ1 görülmektedir (Bıçaksız ve Özkan, 2016). Buna karşılık, Dickman'ın ikili işlevsel ve işlevsiz dürtüsellik yapısını temel alarak, Bıçaksız (2015) tarafından Dürtüsel Sürücü Ölçeği geliştirilmiştir ve uygulanan faktör analizi, dürtüselliğin iki ana faktör yapısına sahip olduğunu ortaya koymuştur. Ayrıca, aynı çalışmada, sürücü işlevsel dürtüselliği, hata ve ihmallerle negatif, olumlu davranışlarla pozitif ilişkili bulunurken; sürücü işlevsiz dürtüselliği siradan ihlal, saldirgan ihlal, ihlal (genel olarak), hata ve ihmallerle pozitif, olumlu davranışlarla negatif ilişkili olduğu bulunmuştur (Bıçaksız, 2015). Yapılan bir başka çalışmada ise, sürücü işlevsel dürtüselliğinin, yanal şerit konumunun standart sapması ile pozitif korelasyona sahip olduğu; sürücü işlevsiz dürtüselliğinin ise ortalama hiz, bildirilmiş hız limitinin üzerinde araç sürülen zamanın ve mesafenin yüzdesi ve şerit dışında sürülen mesafenin yüzdesi ile pozitif korelasyona sahip olduğu bulunmuştur (Bıçaksız, Öztürk ve Özkan, 2019). Genel hatlarıyla bakıldığında dürtüsellik ve sürücü dürtüselliğgi sürücü davranışlarını etkileyen faktörlerden biri olarak ön plana çıkmaktadır.

\subsection{Risk Seviyesi}

Alan yazında, ilgili değişkenlere göre hazırlanan sürüş senaryolarının içeriği ile mevcut çalışmada tanımlanan risk seviyesi tanımı arasında benzerlikler bulunmaktadır, ancak terim olarak risk seviyesi alan yazında daha önce kullanılmamıştır. Mevcut çalışmada, risk seviyesi trafik ortamında sürücülere riskli bir sürüş sunan elementlerin yoğunluğu olarak tanımlanırken, alan yazında trafik yoğunluğu (Nijboer ve ark., 2016) ve trafik karmaşıklığı (Ünal ve ark., 2013) ile paralel bir anlama sahiptir.

Çoklu görev ve sürüş arasındaki ilişkiyi araştıran başka bir çalışmada (Nijboer ve ark., 2016), ilgili değişkeni ölçmek için iki senaryo hazırlanmıştır. Bu senaryolar, trafik yoğunluğu açısından farklılık göstermekte olup, sürücülerin, bir senaryoda trafiğin olmadığ 1 bir yolda araç kullanması beklenirken, diğer senaryoda ise trafiğin olduğu bir yolda araç kullanması beklenmiştir. Katılımcılardan, araç kullanırken ikincil bir görev olarak; radyo dinlemeleri, radyo bilgi yarışmasında sorulara cevap vermesi ve tablet üzerinde bilgi yarışmasına cevap vermeleri beklenmiştir. Sürücüler, en kötü performansını araç kullanırken tablet üzerinde bilgi yarışmasındaki sorulara cevap verirken göstermiştir. İkincil görevlerle birlikte gösterilen sürücü performansı, senaryolara göre değisşiklik göstermiştir. Trafiğin olmadığı sürüş senaryosunda, sürücüler en kötü performansını, araç kullanırken tablet üzerinde bilgi yarışmasındaki sorulara cevap verirken gösterirken, sürücülerin araç kullanırken ikincil bir görev yerine getirmediğinde gösterdiği performans, radyo dinlerken ve radyoda bilgi yarışmasındaki sorulara cevap verirken gösterdiği performanstan daha düşük olduğu bulunmuştur. Trafiğin olduğu senaryoda ise, sürücülerin araç kullanırken ikincil bir görev yerine getirmediğinde ortaya koydukları performans ikinci en düşük performans olarak belirtilirken, radyoda bilgi yarışmasındaki sorulara cevap verirken gösterilen performans sadece radyo dinlenilen durumdan daha düşüktür. Risk seviyesi farklı çalışmalarda farklı şekillerde tanımlanabilirken, bu araştırmada genel olarak sürüş simülasyonu içindeki trafik ortamının unsurlara göre değerlendirilen risk olarak tanımlanmıştır.

Bir başka çalışmada ise, müziğin zihinsel çaba ve sürüş performansı üzerindeki etkisinin incelenmesi için iki senaryo hazırlanmıştır (Ünal ve ark., 2012). Bu senaryolardan biri, tekdüze bir sürüş ortamını içerirken, diğer senaryo park halindeyken aniden hareket eden ve trafik kurallarını ihlal eden araçlar gibi sürücüleri zorlayan çeşitli olayları içermektedir. İki senaryo arasındaki fark zihinsel çaba düzeyi olarak adlandırılmış ve anlamlı bulunmuştur.

\section{TQD}




\section{5. Çalışmanın Amacı}

$\mathrm{Bu}$ çalışmada, sürüş sırasında müzik dinlemenin, sürücü dürtüselliğinin, sürücü risk algısı ve sürüş simülatöründeki sürücü davranışları üzerindeki etkisi incelenmektedir. Alan yazında dürtüselliğin sürücüleri riskli davranışlar sergilemeye teşvik ettiği bilinirken, dürtüselliğin sürücülerin risk algısı üzerindeki etkisi bilinmemektedir. Ancak, önceki çalışmalarla paralel olarak, sürücü işlevsiz dürtüselliği ile ortalama hız arasında pozitif bir ilişki bulunması beklenmektedir. Çalışma araç kullanırken müzik dinlemek, sürücü dürtüselliği ile sürücülerin risk algısı ve davranışları arasındaki ilişkiyi simülasyon ortamında incelemesi açısından alan yazında ilk olma özelliği taşımaktadır.

\section{Yöntem}

\subsection{Katılımcilar}

Çalışmaya, 37'si erkek 13'ü kadın olmak üzere toplam 50 sürücü katılmıştır. Yaşları 18 ile 31 arasında $(O r t=23.70, S S=2.45)$ değişen katılımcılar, aktif olarak araç kullanmaktadır. Katılımcıların en az 6 aydır en çok 11 yıldır ehliyet sahibi oldukları belirlenmiştir $(O r t=4.93$, $S S=2.32)$ ve son bir y1lda kat edilen toplam kilometre 1000 ile 40000 arasinda (Ort $=$ 10711.64, SS $=7758.06)$ değişmekte olup, hayat boyu kat edilen kilometre ise 2000 ile 120000 arasında $(O r t=39604.17, S S=31620.58)$ değişmektedir.

\subsection{Veri Toplama Araçları}

\subsubsection{Demografik Bilgi Formu.}

Çalışmada katılımcıların yaş ve cinsiyet bilgilerini içeren kişisel bilgilerinin yanı sıra son bir yılda ve hayat boyu kat edilen kilometre gibi sürücülük bilgilerini içeren bir demografik bilgi formu kullanılmıştır.

\subsubsection{Dürtüsel Sürücü Ölçeği.}

Bıçaksız (2015) tarafından geliştirilen Dürtüsel Sürücü Ölçeği, sürücü işlevsel ve işlevsiz dürtüselliği ölçmektedir. Ölçek, 35 maddeden ve 2 faktörden oluşmaktadır. Kişilerden kendileri 35 sifatta 5'li Likert tipte (1: beni hiçbir şekilde yansıtmıyor - 5: beni tamamen yansitıyor) nasıl gördüklerini değerlendirmeleri istenmiştir. 23 maddeden oluşan Sürücü İşlevsiz Dürtüselliği faktörü için Cronbach's alpha iç tutarlılık güvenirliği katsayısı .87 (örn: kendini kontrol edemeyen) ve 12 maddeden oluşan Sürücü İşlevsel Dürtüselliği faktörü için Cronbach's alpha iç tutarlılık güvenirliği katsayısı .83 (örn: algısı yüksek olan) olarak hesaplanmıştır.

\subsubsection{Sürüş Simülasyonu.}

Çalışmada, sürüş hızı ve şerit konumu gibi sürücü davranışlarının ölçümü için STISIM Drive M100W (STISIM Drive ${ }^{\circledR}$ Model 100 Wide Field-of-View Complete System) sürüş simülatörü kullanılmıştır. Simülatör toplam 3 ekranda 135 derecelik bir görüş ekranı sunmaktadır. Test ve deney senaryolarında kullanılan araç otomatik vites olarak belirlenmiştir.

Deney senaryosuna geçmeden önce sürüş simülatörü ekipmanlarını ve çevresini tanıtmak ve katılımcıların simülatör hastalığı yaşayıp yaşamadıklarını kontrol etmek amacıyla bir adet test senaryosu sürmeleri istenmiştir. Çalışmada hiçbir katılımcı mide bulantısı gibi simülatör hastalığ etmiştir.

\section{TQD}


Deney senaryosu kapsamında iki senaryo; düşük (DRS) ve yüksek riskli (YRS) tanımlanmıştır. Her bir senaryo 5 kilometre uzunluğunda olup genel bir şehir içi yol şeklinde tasarlanmıştır. Yüksek riskli sürüş senaryosu, sürücüye aniden trafiğe dâhil olan araç ve sağ şeritte çarpışmış 3 araç gibi 10 adet riskli bir sürüş ortamı sağlayan durumu içerirken, düşük riskli sürüş senaryosu bu durumları içermeyip sadece park etmiş araçlar, yayalar gibi çevresel trafik öğeleri içermektedir. Simülatör aracılığıyla ortalama hız, hızdaki standart sapma, ortalama şerit konumu, şerit konumundaki standart sapma şeklinde sürücü davranışlarına dair veriler toplanmıştır.

\subsubsection{Risk Algısı Sorusu.}

Katılımcıların iki farklı sürüş simülasyonunu ne derece riskli değerlendirdiklerini ölçmek adına "Senaryoyu ne kadar riskli değerlendirirsiniz?" sorusu sorulmuş ve katılımcılardan bu soruyu 5'li Likert tip ölçek üzerinde değerlendirmeleri istenmiştir.

\subsubsection{Müzik.}

Mevcut çalışmada müzik değişkeni, ekolojik geçerliliği sağlaması adına (Ünal ve ark., 2012) tercih edilen müzik olarak tanımlanmıştır. Diğer bir deyişle, katılımcılar simülasyon sırasında dinleyecekleri müziğe kendileri karar vermiştir. Mevcut çalışmaya katılmaya gönüllü olan katılımcılar, katılım öncesinde, araç kullanırken dinlemeyi tercih ettikleri beş adet şarkıyı bir form aracılığı ile belirtmiştir. Sadece deney grubundaki katılımcılara, tercih ettikleri şarkıları kendi tercih ettikleri ses şiddetinde iki hoparlör vasıtasıyla dinletilmiştir.

\subsection{Prosedür}

Orta Doğu Teknik Üniversitesi İnsan Araştırmaları Etik Kurulu'ndan etik onay alındıktan sonra, katılımcılara sosyal medya ağları üzerinden uygun ve kartopu örneklem yöntemleri kullanılarak ulaşılmıştır. Her bir katılımcıya randevu verilmeden önce çevrimiçi anket gönderilmiştir. Anket kapsamında katılımcılardan araç kullanırken genellikle dinlemeyi tercih ettiği 5 şarkıyı belirtmeleri istenmiştir. Araştırma ODTÜ - TSK Modsimmer Binası İnsan Faktörü Laboratuvarı'nda gerçekleştirilmiştir. Çalışma kapsamında her bir katılımcı müzik ve kontrol grubu olarak belirlenen iki gruptan birine rasgele atanmıştır. Tüm katılımcılar ilk olarak gönüllü katılım formunu imzalamış ve sürüş simülasyonuna geçmiştir. Sürüş simülatöründe tüm katılımcılar önce test sürüşünü, ardından yüksek riskli ve düşük riskli sürüş senaryosunu tamamlamıştır. Deney grubunda olan katılımcılar sürüş simülasyonundaki sürüssleri daha önceden kendileri tarafından belirtilen şarkılar eşliğinde tamamlarken, kontrol grubunda olan katılımcılar ise müzik olmadan tamamlamıştır. Her bir sürüş sonrasında katılımcılardan sürdükleri senaryonun risk seviyesini değerlendirmeleri üzerine bir soru cevaplamaları istenmiştir. Ardından, bilgisayar ortamında demografik bilgi formu ve Dürtüsel Sürücü Ölçeği doldurulmuştur. Tüm aşamalar sonunda katılımcılara katılım sonrası bilgi formu verilmiştir.

\section{Bulgular}

\subsection{Tanımlayıcı İstatistikler}

Çalışma kapsamında Tablo 1'de gösterildiği üzere katılımcıların yaşı, sürücü belgesine sahip olunan süre, son bir y1lda kat edilen kilometre, hayat boyu kat edilen kilometre, düşük riskli senaryo için risk algısı, yüksek riskli senaryo için risk algısı, yüksek riskli senaryodaki ortalama hız, yüksek riskli senaryoda hızdaki standart sapma, yüksek riskli senaryodaki sürücünün ortalama şerit konumu, yüksek riskli senaryoda sürücünün şerit konumundaki standart sapma, düşük riskli senaryodaki ortalama hız, düşük riskli senaryoda hızdaki standart sapma, düşük riskli senaryodaki sürücünün ortalama şerit konumu, düşük riskli senaryoda

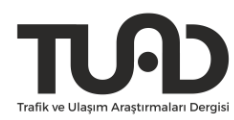


sürücünün şerit konumundaki standart sapması, sürücü işlevsiz dürtüselliği (SİZD), sürücü işlevsel dürtüselliği (SIDD) değiş̧kenleri hesaplanmıştır. Çalışmanın değişkenleri için tanımlayıcı istatistikler (ortalama, standart sapma, minimum ve maksimum değerler) Tablo 1'de sunulmuştur.

Tablo 1. Çalışmanın ana değişkenlerine ait tanımlayıcı istatistikler

\begin{tabular}{lcccc}
\hline & Ort. & $S S$ & Minimum & Maksimum \\
\hline 1. Yaş & 23.70 & 2.45 & 18 & 31 \\
2. Ehliyet süresi & 4.93 & 2.32 & .50 & 11 \\
3. Son bir yılda km & 10710.64 & 7758.06 & 1000 & 40000 \\
4. Hayat boyu km & 39604.17 & 31620.58 & 2000 & 120000 \\
5. Risk algisı (drs) & 1.38 & .64 & 1 & 3 \\
6. Risk algısı (yrs) & 3.88 & .69 & 2 & 5 \\
7. Ortalama hiz (yrs) & 55.71 & 16.17 & 33.03 & 94.50 \\
8. Hız SS (yrs) & 20.91 & 7.33 & 7.83 & 34.76 \\
9. Ortalama şerit konumu (yrs) & 2.52 & .67 & 1.72 & 4.46 \\
10. Şerit konumu SS (yrs) & 1.19 & .33 & .59 & 1.93 \\
11. Ortalama hiz (drs) & 80.12 & 22.46 & 40.96 & 123.00 \\
12. Ortalama hız SS (drs) & 12.69 & 7.32 & 1.90 & 33.23 \\
13. Ortalama şerit konumu (drs) & 2.87 & 1.22 & 1.49 & 5.74 \\
14. Şerit konumu SS (drs) & .91 & .54 & .24 & 1.80 \\
15. İşlevsiz dürtüsellik (SİZD) & 2.13 & .44 & 1.35 & 3.13 \\
16. İşlevsel dürtüsellik (SİD) & 3.93 & .49 & 3.08 & 4.92 \\
\hline
\end{tabular}

Not: Değişkenlerin yüksek riskli senaryodaki değerleri (yrs) ve düşük riskli senaryodaki değerleri (drs) ibareleri ile belirtilmiştir.

\subsection{Korelasyon Analizleri}

Demografik değişkenler, risk algısı, sürüş simülatöründeki sürücü davranışları ve sürücü dürtüselliği boyutları arasındaki ilişkilerin incelenmesi için ikili korelasyon analizi yapılmıştır (Tablo 2).

Demografik değişkenler birbirleriyle pozitif korelasyon göstermiştir. Araştırmanın ana değişkenlerinden risk algısı, düşük riskli sürüş senaryosunda ortalama hız $\left(r=.378^{* *}, p<\right.$ $.01)$ ve ortalama şerit konumunun standart sapması $\left(r=.294^{*}, p<.05\right)$ ile pozitif korelasyon sergilemiştir. Sürücü işlevsel dürtüselliği, son bir yılda kat edilen kilometre ile pozitif korelasyon göstermiştir. $\left(r=.323^{*}, p<.05\right)$. Ayrıca, sürücü işlevsiz dürtüselliği yüksek ve düşük riskli senaryodaki ortalama hız ile pozitif ilişki sergilemiştir. 
Tablo 2. Değişkenler arası ilişkiler

\begin{tabular}{|c|c|c|c|c|c|c|c|c|c|c|c|c|c|c|c|c|}
\hline Değişkenler & 1 & 2 & 3 & 4 & 5 & 6 & 7 & 8 & 9 & 10 & 11 & 12 & 13 & 14 & 15 & 16 \\
\hline 1. Yaş & 1 & & & & & & & & & & & & & & & \\
\hline 2. Ehliyet süresi & $.795 * *$ & 1 & & & & & & & & & & & & & & \\
\hline 3. Hayat boyu km & .135 & $.399 * *$ & 1 & & & & & & & & & & & & & \\
\hline 4. Son bir y1lda km & -.198 & -.003 & $.591 * *$ & 1 & & & & & & & & & & & & \\
\hline 5. Risk alg1s1 (drs) & .086 & .242 & $.398 * *$ & $.297 *$ & 1 & & & & & & & & & & & \\
\hline 6. Risk algis1 (yrs) & -.063 & .216 & $.376 * *$ & .254 & $.295^{*}$ & 1 & & & & & & & & & & \\
\hline 7. Ortalama hiz (yrs) & .163 & .213 & .211 & .193 & $.394 * *$ & .137 & 1 & & & & & & & & & \\
\hline 8. Hiz SS (yrs) & .052 & -.036 & .140 & .069 & .239 & .136 & $.717^{* *}$ & 1 & & & & & & & & \\
\hline $\begin{array}{l}\text { 9. Ortalama şerit } \\
\text { konumu (yrs) }\end{array}$ & -.266 & -.207 & -.150 & .128 & -.067 & .055 & $-.287 *$ & -.125 & 1 & & & & & & & \\
\hline $\begin{array}{l}\text { 10. Şerit konumu SS } \\
\text { (yrs) }\end{array}$ & $-.284 *$ & -.275 & -.160 & .033 & -.195 & -.021 & -.264 & -.068 & $.792 * *$ & 1 & & & & & & \\
\hline 11. Ortalama hiz (drs) & -.049 & .035 & .279 & .182 & $.378 * *$ & .184 & $.643 * *$ & $.711 * *$ & -.085 & -.143 & 1 & & & & & \\
\hline 12. Hiz SS (drs) & -.065 & .059 & .181 & .090 & .274 & .159 & $.390 * *$ & $.453 * *$ & .078 & -.001 & $.735 * *$ & 1 & & & & \\
\hline $\begin{array}{l}\text { 13. Ortalama şerit } \\
\text { konumu (drs) }\end{array}$ & $-.295 *$ & -.256 & -.038 & .209 & -.022 & .140 & $-.295 *$ & -.154 & $.716 * *$ & $.517 * *$ & -.131 & -.055 & 1 & & & \\
\hline $\begin{array}{l}\text { 14. Şerit konumu SS } \\
\text { (drs) }\end{array}$ & .161 & .140 & .187 & .146 & $.294 *$ & .193 & $.357 *$ & $.427 * *$ & .141 & .094 & $.548 * *$ & $.361 *$ & $.290 *$ & 1 & & \\
\hline $\begin{array}{l}\text { 15. İşlevsiz dürtüsellik } \\
\text { (SİZD) }\end{array}$ & -.190 & -.130 & -.087 & -.032 & .266 & -.010 & $.285^{*}$ & $.347 *$ & -.255 & -.259 & $.318^{*}$ & .276 & -.113 & .157 & 1 & \\
\hline $\begin{array}{l}\text { 16. İşlevsel dürtüsellik } \\
\text { (SİD) }\end{array}$ & .245 & .194 & .265 & $.323 *$ & .108 & -.084 & .194 & -.012 & -.089 & -.051 & -.008 & -.037 & .028 & .077 & -.255 & 1 \\
\hline
\end{tabular}

**. Korelasyon 0.01 seviyesinde anlamlıdır.

*. Korelasyon 0.05 seviyesinde anlamlıdir.

Not: Değişkenlerin yüksek riskli senaryodaki değerleri (yrs) ve düşük riskli senaryodaki değerleri (drs) ibareleri ile belirtilmiştir. 


\subsection{Senaryolar ve Risk Algısı}

Sürücülerin yüksek riskli ve düşük riskli senaryolara dair risk algısını karşılaştırmak adına bağımlı örneklem t-test analizi uygulanmıştır. Yapılan analiz sonucunda, yüksek riskli senaryo $($ Ort. $=3.84, S S=.71)$ ve düşük riskli senaryo $($ Ort. $=1.44, S S=.73)$ için risk algıs1 değerleri anlamlı bir fark bulunmuştur $(t(49)=-19.80, p<.001,95 \%$ CI $[-2.64,-2.16])$. Sonuç, sürücülerin daha fazla risk unsurlarına sahip olan sürüş senaryosunu, daha az risk unsurlarına sahip olan sürüş senaryosuna göre daha fazla riskli olarak derecelendirdiğini göstermektedir.

\subsection{Müzik ve Risk Algısı}

Araç kullanırken müzik dinlemenin (müzik var veya yok) ve senaryoların risk düzeyinin (düşük veya yüksek) risk algısına etkisini test etmek için hayat boyu kat edilen kilometrenin istatistiki etkisi kontrol edilerek kovaryans analizi (ANCOVA) uygulanmıştır. Yapılan analiz sonucunda, senaryoların risk düzeyi için risk algısı skorlarında anlamlı bir fark bulunmuştur, $\left(F(1,45)=143.22, p<.001, \eta^{2} p=.76\right)$. Başka bir deyişle, yüksek riskli senaryoda (Ort. $=$ $3.85, S S=.71)$ risk algısı skorları düşük riskli senaryoya $($ Ort. $=1.46, S S=.74)$ kıyasla daha riskli değerlendirilmiştir. Fakat sürüş esnasında müzik dinlemenin risk algısı üzerindeki ana etkisi $\left(F(1,45)=.12, p=.726, \eta^{2} p=.00\right)$ ve sürüş esnasında müzik dinlemenin ve senaryoların risk düzeyinin risk algısı üzerindeki etkileşim etkisi $(F(1,45)=1.651, p=.205$, $\eta^{2} p=.04$ ) anlamlı bulunamamıştır.

Araç kullanırken müzik dinlemenin (müzik var veya yok) ve senaryoların risk düzeyinin (düşük veya yüksek) sürüş simülatöründeki hıza olan etkisini test etmek için hayat boyu kat edilen kilometrenin istatistiki etkisi kontrol edilerek kovaryans analizi (ANCOVA) uygulanmıştır. Yapılan analiz sonucunda, senaryoların risk düzeyinin hız üzerinde etkisi anlamlı bulunmuştur, $\left(F(1,45)=29.22, p<.001, \eta^{2} p=.39\right)$; diğer bir deyişle, sürücüler yüksek riskli senaryo $($ Ort. $=55.17, S S=16.28)$ esnasında aracı düşük riskli senaryoda $(O r t .=$ $80.35, S S=22.68$ ) olduğundan daha düşük bir hızda kullanmışlardır. Araç kullanırken müzik dinlemenin ana etkisi $\left(F(1,45)=.06, p=.814, \eta^{2} p=.00\right)$ ve sürüş esnasında müzik dinlemenin ve senaryoların risk düzeyinin ortalama hız üzerindeki etkileşim etkisi $(F(1,45)=$ $.01, p=.905, \eta^{2} p=.00$ ) anlamlı bulunamamıştır.

Araç kullanırken müzik dinlemenin (müzik var veya yok) ve senaryoların risk düzeyinin (düşük veya yüksek) sürüş simülatöründeki hızın standart sapmasına olan etkisini test etmek için hayat boyu kat edilen kilometrenin istatistiki etkisi kontrol edilerek kovaryans analizi (ANCOVA) uygulanmıştır. Sonuç, senaryoların risk düzeyinin ortalama hızın standart sapması üzerindeki istatistiksel olarak anlamlı bir ana etkisinin olduğunu göstermektedir $(F(1$, $45)=20.86, p<.001, \eta^{2} p=.32$ ). Diğer bir deyişle, yüksek riskli senaryo ortamında (Ort. = $20.72, S S=7.41)$ sürücüler düşük riskli senaryo $($ Ort. $=12.73, S S=7.40)$ ortamında olduğundan daha fazla hız değişimi göstermişlerdir. Ayrıca, sürüş esnasında müzik dinlemenin ana etkisi $\left(F(1,45)=.02, p=.90, \eta^{2} p=.00\right)$ ve sürüş esnasında müzik dinlemenin ve senaryoların risk düzeyinin ortalama hızın standart sapması üzerindeki etkileşim etkisi $\left(F(1,45)=.00, p=.98, \eta^{2} p=.00\right)$ anlamlı bulunamamıştır.

Araç kullanırken müzik dinlemenin (müzik var veya yok) ve senaryoların risk düzeyinin (düşük veya yüksek) sürüş simülatöründeki ortalama şerit pozisyonu üzerindeki etkisini test etmek için hayat boyu kat edilen kilometrenin istatistiki etkisi kontrol edilerek kovaryans analizi (ANCOVA) uygulanmıştır. Yapılan analiz sonucunda, sürüş sırasında müzik dinlemenin ortalama şerit pozisyonu üzerindeki ana etkisi $\left(F(1,45)=2.42, p=.127, \eta^{2} p=\right.$ $.05)$, senaryoların risk düzeyinin ortalama şerit pozisyonu üzerindeki ana etkisinin $(F(1,45)=$ 2.07, $\left.p=.157, \eta^{2} p=.04\right)$ ve sürüş esnasında müzik dinlemenin ve senaryo risk düzeylerinin

\section{TQD}


ortalama şerit pozisyonu üzerindeki etkileşim etkisi $\left(F(1,45)=.21, p=.650, \eta^{2} p=.00\right)$ anlamlı bulunamamıştır.

Araç kullanırken müzik dinlemenin (müzik var veya yok) ve senaryoların risk düzeyinin (düşük veya yüksek) sürüş simülatöründe şerit pozisyonunun standart sapması üzerindeki etkisini test etmek için hayat boyu kat edilen kilometrenin istatistiki etkisi kontrol edilerek kovaryans analizi (ANCOVA) uygulanmıştır. Yapılan analiz sonucunda, senaryoların risk düzeyinin ortalama şerit konumunun standart sapması üzerinde istatistiksel olarak anlamlı bir etkisi bulunmuştur, $\left(F(1,45)=11.82, p<.001, \eta^{2} p=.21\right)$. Diğer bir deyişle, sürücülerin yüksek riskli sürüş ortamında $($ Ort. $=1.2, S S=.33)$ düşük riskli sürüş ortamında $($ Ort. $=.91$, $S S=.54$ ) olduğundan daha fazla şerit değiştirdikleri bulunmuştur. Sürüş esnasında müzik dinlemenin ortalama şerit pozisyonun standart sapması üzerindeki ana etkisi $(F(1,45)=2.66$, $\left.p=.110, \eta^{2} p=.06\right)$ ve sürüş esnasında müzik dinlemenin ve senaryo risk düzeylerinin ortalama şerit pozisyonunun standart sapması üzerindeki etkileşim etkisi $(F(1,45)=.871, p=$ $.356, \eta^{2} p=.02$ ) anlamlı bulunamamıştır.

\subsection{Sürücü Dürtüselliği, Risk Algısı ve Sürücü Davranışları}

Yapılan korelasyon analizine göre, sürücü işlevsiz dürtüselliğinin simülatördeki sürücü davranışları ile ilişkili olduğu bulunmuştur. Sürücü işlevsiz dürtüselliği, median-split yöntemi kullanılarak yüksek ve düşük olarak üzere iki düzeye ayrılmıştır (Tablo 3.). Araştırmanın değişkenlerinin sürücü işlevsiz dürtüselliği açısından karşılaştırılması için bağımsız örneklemler t-testi yapılmıştır. Yapılan analiz sonucunda, sürücü işlevsiz dürtüselliği, düşük risk seviyeli sürüş ortamındaki risk algısı $(t(1,48)=2.29, p<.05,95 \%$ CI $[.05, .84])$, yüksek riskli senaryodaki sürücünün ortalama hız1 $(t(1,48)=2.87, p<.05,95 \%$ CI $[3.6,20.6])$, yüksek riskli senaryodaki sürücünün hızının standart sapması $(t(1,48)=2.14, p<.05,95 \% \mathrm{CI}$ $[.27,8.3])$, yüksek riskli senaryodaki sürücünün ortalama şerit konumu $(t(1,48)=-2.04, p<$ $.05,95 \%$ CI $[-.77,-.00])$, yüksek riskli senaryodaki sürücünün şerit konumunun standart sapması $(t(1,48)=-2.39, p<.05,95 \%$ CI $[-.39,-.03])$ düşük riskli senaryodaki sürücünün ortalama hizı $(t(1,48)=2.129, p<.05,95 \%$ CI $[.73,25.4])$ ile anlamlı bir farklılık göstermiştir. Başka bir ifadeyle, yüksek SİZD’ye sahip sürücüler, aracı şeridin daha solunda kullandıkları ve şerit konumlarını daha az değiştirdikleri, düşük riskli sürüş ortamında; daha yüksek risk algısı skorlarına sahip oldukları ve daha yüksek ortalama hız gösterdikleri bulunmuştur.

Tablo 3. Sürücü işlevsiz dürtüselliği açısından tanımlayıcı istatistikler

\begin{tabular}{lllll}
\hline & İşlevsiz D. & S & Ort. & SS \\
\hline 1. Risk algısı (drs) & 1 & 26 & 1.65 & .89 \\
2. Risk algısı (yrs) & 2 & 24 & 1.21 & .41 \\
& 1 & 26 & 3.77 & .65 \\
3. Ortalama hız (yrs) & 2 & 24 & 3.92 & .78 \\
& 1 & 26 & 61.51 & 17.76 \\
4. Ortalama hız SS (yrs) & 2 & 24 & 49.42 & 11.62 \\
& 1 & 26 & 22.97 & 7.17 \\
5. Ortalama şerit konumu (yrs) & 2 & 24 & 18.68 & 6.96 \\
& 1 & 26 & 2.36 & .38 \\
6. Ortalama şerit konumu SS (yrs) & 2 & 24 & 2.72 & .85 \\
& 1 & 26 & 1.09 & .24 \\
7. Ortalama hız (drs) & 2 & 24 & 1.30 & .37 \\
8. Ortalama hız SS (drs) & 1 & 26 & 86.38 & 22.30 \\
& 2 & 24 & 73.33 & 21.03 \\
& 1 & 26 & 14.17 & 6.51 \\
\hline
\end{tabular}


Tablo 3. Devam

\begin{tabular}{lllll}
\hline 9. Ortalama şerit konumu (drs) & 1 & 26 & 2.73 & .91 \\
& 2 & 24 & 3.03 & 1.48 \\
10. Ortalama şerit konumu SS (drs) & 1 & 26 & .99 & .57 \\
& 2 & 24 & .83 & .50
\end{tabular}

Not: Sürücü işlevsiz D. = 1 (Yüksek sürücü işlevsiz dürtüselliği), İşlevsiz D. = 2 (düşük sürücü işlevsiz dürtüselliği)

\section{Tartışma}

$\mathrm{Bu}$ çalışma kapsamında, araç kullanırken müzik dinlemenin ve sürücü dürtüselliğinin, sürücülerin risk algısı ve sürüş simülasyonundaki sürücü davranışları üzerindeki etkisi incelenmiştir. İlgili alan yazında ve diğer disiplinler arası kaynaklarda, mevcut makalenin değişkenleri arasındaki ilişkiler bu doğrultuda incelenmemiştir.

Risk algısı seviyesinin sürücünün deneyim düzeyi ile arttığı alan yazında bazı çalışmalarda belirtilmiştir (Deery, 1999; Machin ve Sankey, 2008). Bu bulgular ile paralel olarak, mevcut çalışmada da düşük ve yüksek riskli senaryolarda, hayat boyu kat edilen kilometre arttıkça risk algısındaki seviyenin arttığına ulaşılmıştır. Sürücülerin trafik ortamına daha fazla maruz kalmasının, trafik ortamında algıladıkları riski artırabileceği görülmektedir. Mevcut çalışmada DRS'deki ortalama hız ile DRS'deki risk algısı arasında pozitif bir ilişki bulunmuştur. Aynı zamanda, risk algısı ve ortalama hız DRS'de artış göstermiştir. DRS'de risk algııı ve ortalama hız arasında pozitif bir korelasyon bulunması, araştırmacılar tarafından hazırlanmış sürüş senaryolarından kaynaklanmış olabilir. Alan yazında sürücülerin yoldaki belirsizliği azaltmak için gerekli bilgiyi elde etmeye ihtiyaç duyduğu fakat yoldaki işlenmesi gereken bilgi fazla ise sürücünün bunu telafi etmesi için hızını azalttığı gösterilmiştir (Senders, Kristofferson, Levison, Dietrich ve Ward, 1967). DRS'de belirsizliği arttırıp hızı düşürecek faktörlerden araç, bisikletli ve yaya unsurlarının sayıca yüksek riskli senaryoya göre düşük olması kişilerde işlenmesi gereken bilgi yoğunluğunu azalttığı için bu kişilerde risk algısı yüksek olsa da senaryonun düzeni hız artışına ortam hazırlamış olabilir. Alan yazında, orta seviyede hayat boyu kat edilen mesafeye sahip sürücülerin, düşük seviyede hayat boyu kat edilen mesafeye sahip sürücülere göre daha yüksek sürücü işlevsel dürtüselliğine sahip olduğu raporlanmıştır (Bıçaksız, 2015). Bu bulguya uygun olarak, mevcut çalışmada sürücü işlevsel dürtüselliği son bir yılda kat edilen toplam mesafe ile pozitif korelasyona sahip olduğu bulunmuştur.

Mevcut çalışmada, sürücü işlevsel dürtüselliğinin, çalışmanın sadece tek bir değişkeni ile (son bir yılda kat edilen toplam mesafe) ilişkili olduğu raporlanmıştır. Bu durum, ölçüm yapılarındaki farklılıklar ile açıklanabilmektedir. Dürtüsel Sürücü Ölçeği'nin kişinin kendi öz raporlamasına dayalı bir ölçek olduğu belirtilmiştir (Bıçaksız, 2015). Dolayısıyla, bu ölçek, kişilerin belirli bir ortamda gösterdiği davranışlardan ziyade, kendilerinin belirli sorular çerçevesindeki öz değerlendirmesini ortaya koymaktadır. Çalışmanın çoğu değişkeni ise sürüş simülasyonu verisine dayandığı için kişinin gözlemlenebilen davranışları ölçülmüştür. $\mathrm{Bu}$ farklılık, sürücü işlevsel dürtüselliği ile diğer değişkenler arasında herhangi bir ilişki bulunamamasını açıklayabilir. Ancak sürücü işlevsiz dürtüselliğinin, sürücü işlevsel dürtüselliğine göre mevcut çalışmanın diğer değişkenleri ile daha fazla korelasyon sonucu vermesi, bu açıklamaya bir kısıtlılık yaratmaktadır. Bu durum ise, SİZD boyutunun SİD’ye göre sürüş simülasyonunda daha belirgin gözlenebildiği ile yorumlanabilir.

Dürtüselliğin riskli sürücü davranışları için etkin rolü, mevcut çalışmada da sürüş simülatörü kullanılarak araştırılmıştır. Alan yazında, hem dürtüsellik ve riskli sürücü davranışları (hızlı araç kullanmak vb.; Dahlen ve ark., 2005) hem de dürtüsellik ve hızlı araç kullanma (Ryb ve ark., 2006) arasında pozitif bir korelasyona ulaşan çalışmalar mevcuttur. Ayrıca, Si̇ZD ve sıradan ihlaller (hız sınırını aşmak vb.) arasında pozitif korelasyona ulaşılmıştır (Bıçaksız,




2015). Bu bulgular ile paralel olarak, mevcut çalışmada da yüksek Si̇ZD’ye sahip sürücülerin trafik ortamındaki risk seviyesi fark etmeksizin daha hızlı araç kullandığına ulaşılmıştır.

Yüksek SİZD'ye sahip sürücüler, düşük SİZD'ye sahip sürücülere göre, DRS'yi daha riskli algılarken YRS'yi daha az riskli değerlendirmişlerdir. Sürücülerin sahip olduğu dürtüselliğin işlevsiz ve yüksek oluşu, bu sürücülerin trafik ortamındaki risk unsurları ile başa çıkamadığını ve dolayısıyla risk algısında problem yarattığını ortaya koymaktadır. Ayrıca, dürtüselliğin diğer sürücü davranışlarına olan etkisi incelendiğinde, yüksek SİZD'ye sahip sürücüler, düşük SIZD'ye sahip sürücülere göre YRS'de daha fazla hız değişimi yaptıkları, ortalama şerit konumlarının daha solda olduğu ve şerit konumlarını daha az değiştirdikleri bulunmuştur. $\mathrm{Bu}$ bulgular, yüksek SİZD'ye sahip sürücülerin, kendi şeritlerinde karşılaştıkları riskli unsurlardan kaçınmak adına daha solda araç kullandıklarını ve şerit konumlarını koruduklarını göstermektedir. Alan yazın incelendiğinde, şerit konumunu koruma davranışının dikkat dağıtıcılar etkisi altında iki yönlü değişiklik gösterdiği, sürücülerin araç kullanırken bilişsel dikkat dağıtıcı bir görev tamamlamasının hem şerit konum değişkenliğini (Just ve ark., 2008) hem de şerit konumunu sürdürmeyi arttırdığı (Brookhuis ve ark., 1991) bulunmuştur. Mevcut çalışmada her ne kadar araç kullanırken müzik dinlemenin sürücü davranışına herhangi bir etkisi bulunmasa da yüksek SİZD’ye sahip sürücülerin araç kullanırken bilişsel bir dikkat dağıtıcı olan müzik dinleme sırasında şerit konumlarını korumaları, tartışmalı bulguların bir yönüne destek olabilmektedir. Bunun yanı sıra, mevcut çalışmada yaş artışıyla birlikte sürücülerin düşük ve yüksek riskli sürüş ortamında daha az şerit konumu değiştirdikleri ortaya konmuştur. Bu bulgu, alan yazındaki genç ve yaşlı sürücülerin şerit konumu değişiminin orta yaşlı sürücülere göre daha fazla olduğu bulgusu (Peng, Boyle ve Hallmark, 2013) ile paraleldir.

Mevcut çalışmada, müzik ekolojik geçerliliği artırması adına (Ünal ve ark., 2012) tercih edilen müzik olarak tanımlanmıştır. Diğer bir deyişle, katılımcılar dinleyecekleri müziğe kendileri karar vermiştir. Doğal ortamlarında sürücüler, araç kullanırken dinledikleri şarkıları kendileri seçmektedirler. Şarkıyı özel olarak seçmedikleri durumlarda bile, herkesin tercih ettiği bir radyo kanalı veya daha önce hazırlanmış şarkı listesi bulunmaktadır. Dolayısıyla, araştırmada müzik değişkeni tanımlanırken kişinin doğal ortamındaki davranışının kullanılmasına karar verilmiştir. Böylece, araştırmanın bulguları, sürücülerin doğal ortamda sergilediği davranışlarını yansıtmakta ve günlük hayata daha uygulanabilir çıkarımlara ulaşılmasını sağlamaktadır. İlgili alan yazın incelendiğinde, bazı çalışmalarda müziğin sürücü davranışına ve performansına bir etkisi olduğu (Brodsky ve Slor, 2013; Ünal ve ark., 2013) gözlemlenirken bazı çalışmalarda ise bir etkisinin olmadığı (Santoso ve ark., 2013; Beh ve Hirst, 1999) bulunmuştur. Müzik değişkenini, kişinin kendi tercih ettiği müzik ve araştırmacılar tarafından belirlenen müzik şeklinde sınıflandıran Brodsky ve Slor (2013), sürücülerin kendi tercih ettiği müziği dinlerken araştırmacılar tarafından belirlenen müziğe göre daha kusurlu araç kullandıklarını ortaya koymuştur. Bunun yanı sıra, Ünal ve ark. (2013), tercih edilen müziği dinlemenin sürücü performansını geliştirdiğini bulmuştur. Müziğin kişinin kendi tercihine bırakılmayan ve ses şiddeti (Beh ve Hirst, 1999) ve janr (Santoso ve ark., 2013) gibi yapılar üzerinden tanımlamasının yapıldığı çalışmalara bakıldığında ise, araç kullanırken müzik dinlemenin sürücü davranışı ve performansına anlamlı bir etkisi olmadığı bulunmuştur. Alan yazın, bu şekilde karşılaştırıldığında, müzik tercihinin kişiye bırakılmasıyla sürücü davranışı üzerinde anlamlı etki bulmanın daha olası olduğu çıkarımı yapılabilir. Buna rağmen, müzik daha farklı bir sınıflandırma yapılarak uygulansayd1, anlamlı bir etki bulunabilirdi. Müzik, çok çeşitli yapılardan oluşan ve dolayısıyla kendi içinde kontrol edilmesi gereken bir uyarandır. Şarkı sözü içermesi veya içermemesi (enstrümantal), şarkı sözü içeriyorsa sözün dili (anadil, ikinci dil, aşina olunan dil,

\section{TQD}


aşina olunmayan dil vb.), türü, ses şiddeti, temposu, yarattığı duygu ve ruh hali, aşinalık, tercih edilme gibi çok çeşitli yapıları kontrol edildiğinde daha anlamlı sonuçlar elde edilebilir.

Araç kullanırken müzik dinlemek, araç kullanma görevinin yanı sıra ortaya koyulan bir davranış olarak ele alındığında, müzik dinlemek ikincil görev olarak, aynı anda araç kullanmak ve müzik dinlemek ise çoklu görev olarak tanımlanabilmektedir. İlgili alan yazın çoklu görev, risk algısı ve dürtüsellik ilişkisi açısından incelendiğinde, yüksek dürtüselliğe sahip bireylerin, düşük dürtüselliğe sahip bireylere göre çoklu görev yerine getirirken daha yüksek performans gösterdiği bulunmuştur (Sanbonmatsu ve ark., 2013). Bunun yanı sıra, düşük dürtüselliğe sahip bireylerinse araç kullanırken müzik dinlediklerinde daha dikkatli araç kullandıkları ortaya konmuştur (Brodsky ve Slor, 2013). İlgili alan yazındaki bulgulara rağmen, mevcut çalışmada araç kullanırken müzik dinlemenin çalışmanın hiçbir değişkeni ile ilişki olmadığı raporlanmıştır.

Araç kullanırken müzik dinlemenin sürücü davranışına ve sürücünün risk algısına anlamlı bir etkisinin olmaması, araştırmacılar tarafından hazırlanmış sürüş senaryolarından kaynaklanmış olabilir. Sürücüler, YRS 'yi kullanırken yoğun risk unsurları ile başa çıkarken, sürüş sırasında çalan müziğin uyarıcı rolü azaltmış ve hatta kaybolmuş olabilir. Ünal ve ark. (2013), sürücülerin araç kullanırken gerçekleştirdikleri başka bir görev sırasında, ana görevlerine odaklanmak için herhangi bir bilişsel strateji geliştirip geliştirmediklerine yönelik bir çalışma gerçekleştirmiştir. İki aşamadan oluşan bu çalışmanın ilk ayağında, katılımcılar radyo programı dinlemiş ve ardından programın içeriğine dair soruları yanıtlamışlardır. İkinci çalışmada ise, sürücüler bir sürüş simülatöründe araç kullanırken radyo programı dinlemiş ve programın içeriğine dair soruları yanıtlamışlardır. İki çalışmanın sonuçları karşılaştırıldığında, sürücülerin araç kullanırken radyo programının içeriğine dair sorulara daha az doğru yanıt verdikleri ve dolayısıyla araç kullanırken gerçekleştirdikleri ikinci görevi bloke ettikleri ortaya konmuştur (Ünal ve ark., 2013). Mevcut çalışmada da sürücüler araç kullanırken diğger bir görevi (müzik dinlemek) bloke ettikleri söz konusu olabilir.

Mevcut çalışmanın bazı kısıtlılıkları vardır. Çalışmanın ilk kısıtlılı̆̆ı, araç kullanırken müzik dinleme değişkeni için denekler arası dizaynının kullanılmasıdır. Katılımcıların yarısı sürüş senaryolarını kullanırken müzik dinlemiş, diğer yarısı ise dinlememiştir. $\mathrm{Bu}$ dizaynın kullanılması, homojen olmayan iki farklı grup ile çalışmış olma ve homojen olmayan iki farklı grubun çıktılarının karşılaştırılmış olması ihtimalini ortaya çıkarmaktadır (Tabachnick, Fidell ve Osterlind, 2001). İlerleyen çalışmaların aynı örneklem ile farklı koşullarda gerçekleştirilmesi bulguların güvenilirliği ve geçerliğini test etmek adına önemlidir. Çalışmanın ikinci kısıtlılığı, katılımcıların sosyal istenirliğe olası eğilimidir. Katılımcılar, anketleri doldururken kendileri için doğru olan cevapları vermek yerine toplumsal olarak kabul ve tercih edilen cevapları vermiş olabilir. $\mathrm{Bu}$ durum, katılımcıların sürüş simülatöründeki davranış için de geçerlidir. Kendi hayatında trafik kurallarını ihlal eden bir sürücü, sosyal istenirlik eğilimine sahipse, sürüş simülatöründe trafik kurallarını ihlal etmemeye dikkat ederek araç kullanabilir. Fakat Lajunen ve Parker (2001) gizliliğe ve güvenliğe önem veren çalışmalarda sosyal istenirlik etkisinin daha düşük olabileceğini önermiştir.

$\mathrm{Bu}$ çalışmada, araç kullanırken müzik dinlemenin ve sürücü dürtüselliğinin, sürücülerin risk algıs1 ve sürücü davranışları üzerindeki etkisi, bir sürüş simülatörü ve öz bildirim sürücü dürtüselliği ölçeği kullanılarak Türkiye örnekleminde incelenmiş ve bu açıdan literatüre katkı sağlamıştır. Mevcut çalışmada araştırılan değişkenler alan yazında daha önce birlikte çalışılmamıştır, bu yönden, bu araştırma sorusu ile alan yazına katkı sağlama hedeflenmiştir. Yukarıda da tartışıldığı üzere, sürücü dürtüselliğinin -özellikle SİZD- yol güvenliği için araştırılması gereken bir kavram olduğu bu araştırmada da ortaya konmuştur. Türkiye




İstatistik Kurumu'nun verilerine göre, 2017 yılında gerçekleşen ölümlü yaralanmalı kazalara neden olan sürücü kusurlarının \%42'si, belirlenen hız şartlarına ve sınırlarına uyulmamasıdır. Mevcut çalışmada ulaşılan SİZD ile ortalama hız arasındaki pozitif yöndeki ilişki, bu sürücü grubunun trafik ortamı için risk teşkil edebileceğini göstermektedir. Dolayısıyla, daha hızlı araç kullanan yüksek SİZD’ye sahip sürücüler için, hızı düşürmeye yönelik müdahale programları geliştirilebilir. Böylece, belirlenen hız şartlarına ve sınırlarına uyulmamasından kaynaklanan ölümlü yaralanmalı kaza sayısı azalacak ve yol güvenliği artacaktır. Türkiye genelinde ehliyet kurslarında sürücü adaylarına sağlanan teorik eğitimin içeriği, yol güvenliği ile daha da fazla desteklenebilir. Ayrıca, bu eğitime yol güvenliği farkındalığını arttırmaya yönelik içerikler eklenebilir. Riskli olarak değerlendirilen bu grup, eğitim öncesi veya sonrasında uzmanlar tarafindan tespit edilebilir. Ayrıca, bu grup trafik ortamına henüz dâhil olmadan, bu grubun hıza yönelik yatkınlığını azaltmaya yönelik müdahaleler yapılabilir. Araç kullanırken müzik dinlemenin, sürücünün sürüş sırasında bilişsel algısına etkileri, odak ve dikkat kavramları ile çalışıldığında anlamlı sonuçlara ulaşılacaktır. 


\section{Kaynakça}

Arce, E. ve Santisteban, C. (2006). Impulsivity: A review. Psicothema, 18(2), 213-220.

Barratt, E. S. (1972). Anxiety and impulsiveness: toward a neuropsychological model. In: Spielberger, C. (Ed.), Current Trends in Theory and Research, Vol. 1. Academic Press, New York, 195-222.

Barratt, E. S. (1985). Impulsiveness subtraits: Arousal and information processing. Motivation, Emotion, and Personality, 5, 137-146.

Beh, H. C. ve Hirst, R. (1999). Performance on driving-related tasks during music. Ergonomics, 42(8), 1087-1098.

Bıçaksız, P. (2015). The Differential Associations of Functional and Dysfunctional Impulsivity with Driver Behaviors and Skills, Accidents and Offences (Yayınlanmamış Doktora Tezi). Orta Doğu Teknik Üniversitesi, Ankara.

Bıçaksız, P. ve Özkan, T. (2016). Developing the Impulsive Driver Behavior Scale. Transportation Research Part F: Traffic Psychology and Behaviour, 43, 339356.

Bıçaksız, P., Öztürk, İ. ve Özkan, T. (2019). The differential associations of functional and dysfunctional impulsivity with driving style: A simulator study. Transportation Research Part F: Traffic Psychology and Behaviour, 63, 1-11.

Brodsky, W. (2001). The effects of music tempo on simulated driving performance and vehicular control. Transportation Research Part F: Traffic Psychology and Behaviour, 4(4), 219-241.

Brodsky, W. ve Slor, Z. (2013). Background music as a risk factor for distraction among young-novice drivers. Accident Analysis and Prevention, 59, 382-393.

Brookhuis, K. A., de Vries, G. ve de Waard, D. (1991). The effects of mobile telephoning on driving performance. Accident Analysis and Prevention, 23(4), 309-316.

Brown, I. D. ve Groeger, J. A. (1988). Risk perception and decision taking during the transition between novice and experienced driver status. Ergonomics, 31, 585-597.

Buss, A. H. ve Plomin, R. (1975). A temperament theory of personality development. WileyInterscience.

Caci, H., Nadalet, L., Baylé, F. J., Robert, P. ve Boyer, P. (2003). Functional and dysfunctional impulsivity: contribution to the construct validity. Acta Psychiatrica Scandinavica, 107(1), 34-40.

Cassidy, G. G. ve MacDonald, R. A. R. (2010). The effects of music on time perception and performance of a driving game. Scandinavian Journal of Psychology, 51(6), 455-464.

Cohn, L.D., Macfarlane, S. ve Yanez, C. (1995). Risk-perception: Differences between adolescents and adults. Health Psychology, 14(3), 217-222.

Cyders, M. A., Smith, G. T., Spillane, N. S., Fischer, S., Annus, A. M. ve Peterson, C. (2007). Integration of impulsivity and positive mood to predict risky behavior: Development and validation of a measure of positive urgency. Psychological Assessment, 19(1), 107-118.

\section{TOD}


Dahlen, E. R., Martin, R. C., Ragan, K. ve Kuhlman, M. M. (2005). Driving anger, sensation seeking, impulsiveness, and boredom proneness in the prediction of unsafe driving. Accident Analysis and Prevention, 37(2), 341-348.

Deery, H. A. (1999). Hazard and Risk Perception among young novice drivers. Safety Research, 30(4), 225-236.

de Oña, J., de Oña, R., Eboli, L., Forciniti, C. ve Mazzulla, G. (2014). How to identify the key factors that affect driver perception of accident risk. A comparison between Italian and Spanish driver behavior. Accident Analysis and Prevention, 73, 225-235.

Di Milia, L. (2013). A revised model of Dickman's Dysfunctional Impulsivity Scale. Journal of Individual Differences, 34, 138-142. doi:10.1027/1614-0001/a000107

Dibben, N. ve Williamson, V. J. (2007). An exploratory survey of in-vehicle music listening. Psychology of Music, 35(4), 571-589.

Dick, D. M., Smith, G., Olausson, P., Mitchell, S. H., Leeman, R. F., O'malley, S. S. ve Sher, K. (2010). Understanding the construct of impulsivity and its relationship to alcohol use disorders. Addiction Biology, 15(2), 217-226.

Dickman, S. J. (1990). Functional and dysfunctional impulsivity: Personality and cognitive correlates. Journal of Personality and Social Psychology, 58(1), 95-102.

Febriandirza, A., Chaozhong, W., Zhong, M., Hu, Z. ve Zhang, H. (2017). The effect of natural sounds and music on driving performance and physiological. Engineering Letters, 25(4).

Ferdinand, A. O. ve Menachemi, N. (2014). Associations between driving performance and engaging in secondary tasks: A systematic review. American Journal of Public Health, 104(3), 39-48.

Haddon, W. (1972). A logical framework for categorizing highway safety phenomena and activity. The Journal of Trauma, 12(3), 193-207.

Harbeck, E. L. ve Glendon, A. I. (2013). How reinforcement sensitivity and perceived risk influence young drivers' reported engagement in risky driving behaviors. Accident Analysis and Prevention, 54, 73-80.

HaSPA (2012). The Core Body of Knowledge for Generalist OHS Professionals. Tullamarine, VIC. Safety Institute of Australia.

Havârneanu, G. M. ve Havârneanu, C. E. (2012). When norms turn perverse: Contextual irrationality vs. rational traffic violations. Transportation Research Part F: Traffic Psychology and Behaviour, 15(2), 144-151.

Hayashi, Y., Rivera, E. A., Modico, J. G., Foreman, A. M. ve Wirth, O. (2017). Texting while driving, executive function, and impulsivity in college students. Accident Analysis and Prevention, 102, 72-80.

Hughes, G. M., Rudin-Brown, C. M. ve Young, K. L. (2013). A simulator study of the effects of singing on driving performance. Accident Analysis and Prevention, 50, 787-792.

Jimison, Z. N. (2014). The Effect of Music Familiarity on Driving: A Simulated Study of the Impact of Music Familiarity Under Different Driving Conditions. (Yayınlanmamıs, Doktora Tezi). Kuzey Florida Üniversitesi, Jacksonville, Florida.

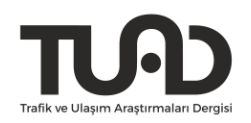


Jonah B. A. (1986). Accident risk and risk-taking behaviour among young drivers. Accident Analysis and Prevention, 18(4), 255-271.

Jovanović D., Stanojević P. ve Jakšić D. (2014). The influence of risk perception and selfassessed driving abilities on the behavior of young drivers. XII International Symposium. Road Accident Prevention, 9-10.

Just, M. A., Keller, T. A. ve Cynkar, J. (2008). A decrease in brain activation associated with driving when listening to someone speak. Brain Research, 1205, 70-80.

Kanellaidis, G., Zervas, A. ve Karagioules, V. (2000). Drivers Risk Perception of Road Design Elements. Transportation Human Factors, 2(1), 39-48.

Kovácsová, N., Lajunen, T. ve Rošková, E. (2016). Aggression on the road: Relationships between dysfunctional impulsivity, forgiveness, negative emotions, and aggressive driving. Transportation Research Part F: Traffic Psychology and Behaviour, 42, 286298.

Lajunen, T. ve Parker, D. (2001). Are aggressive people aggressive drivers? A study of the relationship between self-reported general aggressiveness, driver anger and aggressive driving. Accident Analysis and Prevention, 33, 243-255.

Lassiter, G. H. (2009). Impulsivity: Causes, Control and Disorders. Nova Biomedical Books., New York, NY, 59-82.

Luk, J. W., Trim, R. S., Karyadi, K. A., Curry, I., Hopfer, C. J., Hewitt, J. K., ... ve Wall, T. L. (2017). Unique and interactive effects of impulsivity facets on reckless driving and driving under the influence in a high-risk young adult sample. Personality and Individual Differences, 114, 42-47.

Lund, I. O. ve Rundmo, T. (2009). Cross-cultural comparisons of traffic safety, risk perception, attitudes and behaviour. Safety Science, 47(4), 547-553.

Machin, M. A. ve Sankey, K. S. (2008). Relationships between young drivers' personality characteristics, risk perceptions, and driving behaviour. Accident Analysis and Prevention, 40(2), 541-547.

Ngueutsa, R. ve Kouabenan, D. (2017). Fatalistic beliefs, risk perception and traffic safe behaviors. Revue Européenne de Psychologie Appliquée, 67(6), 307-316.

Nijboer, M., Borst, J. P., van Rijn, H. ve Taatgen, N. A. (2016). Driving and multitasking: the good, the bad, and the dangerous. Frontiers in Psychology, 7, 1718.

North, A. C. ve Hargreaves, D. J. (1999). Music and driving game performance. Scandinavian Journal of Psychology, 40(4), 285-292.

O'Brien, F. ve Gormley, M. (2013). The contribution of inhibitory deficits to dangerous driving among young people. Accident Analysis and Prevention, 51, 238-242.

Özkan, Ö., Öztürk, İ. ve Öz, B. (2018). Trafik güvenliği bağlamında dürtüsel sürücülüğün sürücü öfke ifadesi ile ilişkisi. Güvenlik Bilimleri Dergisi, 7(2), 329-354. doi:10.28956/gbd482092

Peng, Y., Boyle, L. N. ve Hallmark, S. L. (2013). Driver's lane keeping ability with eyes off road: Insights from a naturalistic study. Accident Analysis and Prevention, 50, 628634.

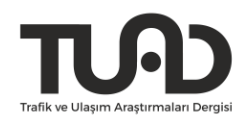


Ponnaluri, R.V. (2011). Road traffic crashes and risk groups in India: Analysis, interpretations, and prevention strategies. IATSS Research, 35, 104-110.

Ram, T. ve Chand, K. (2016). Effect of drivers' risk perception and perception of driving tasks on road safety attitude. Transportation Research Part F: Traffic Psychology and Behaviour, 42, 162-176.

Renge, K. (1998). Drivers' hazard and risk perception, confidence in safe driving, and choice of speed. IATSS Research, 22(2), 103-110.

Rhodes, N. ve Pivik, K. (2011). Age and gender differences in risky driving: The roles of positive affect and risk perception. Accident Analysis and Prevention, 43(3), 923-931.

Ryb, G. E., Dischinger, P. C., Kufera, J. A. ve Read, K. M. (2006). Risk perception and impulsivity: association with risky behaviors and substance abuse disorders. Accident Analysis and Prevention, 38(3), 567-573.

Sanbonmatsu, D. M., Strayer, D. L., Medeiros-Ward, N. ve Watson, J. M. (2013). Who multitasks and why? Multi-tasking ability, perceived multi-tasking ability, impulsivity, and sensation seeking. PLoS ONE, 8(1), e54402. doi:10.1371/journal.pone.0054402

Santoso, G. A., Maulina, D., Adystia, C. ve Oei, T. P. (2013). The influence of number of passengers and music genre on driving speed of young adult angkot drivers. Transportation Research Part F: Traffic Psychology and Behaviour, 18, 1-10.

Senders, J., Kristofferson, A., Levison, W., Dietrich, C. ve Ward, J. (1967). The attentional demand of automobile driving. Highway Research Record, 196, 15-32.

Smorti, M. ve Guarnieri, S. (2016). Do aggressive driving and negative emotional driving mediate the link between impulsiveness and risky driving among young Italian drivers?. The Journal of Social Psychology, 156(6), 669-673.

Steinberg, L., Albert, D., Cauffman, E., Banich, M., Graham, S. ve Woolard, J. (2008). Age differences in sensation seeking and impulsivity as indexed by behavior and selfreport: evidence for a dual systems model. Developmental Psychology, 44(6), 1764.

Tabachnick, B. G., Fidell, L. S. ve Osterlind, S. J. (2001). Using multivariate statistics.

Titchener, K., White, M. J. ve Kaye, S. A. (2009). In-vehicle driver distractions: Characteristics underlying drivers' risk perceptions. In: Proceedings, 10-12 Kasim 2009, Sydney Convention and Exhibition Centre, Sydney, New South Wales.

TÜİK (2017). Karayolu Trafik Kaza İstatistikleri, 2017

Ulleberg, P. ve Rundmo, T. (2003). Personality, attitudes and risk perception as predictors of risky driving behavior among young drivers. Safety Science, 41(5), 427-443.

Ünal, A. B., de Waard, D., Epstude, K. ve Steg, L. (2013). Driving with music: Effects on arousal and performance. Transportation Research Part F: Traffic Psychology and Behaviour, 21, 52-65.

Ünal, A. B., Steg, L. ve Epstude, K. (2012). The influence of music on mental effort and driving performance. Accident Analysis and Prevention, 48, 271-278.

Van Der Zwaag, M. D., Dijksterhuis, C., de Waard, D., Mulder, B. L., Westerink, J. H. ve Brookhuis, K. A. (2012). The influence of music on mood and performance while driving. Ergonomics, 55(1), 12-22.

\section{TQD}


Wang, D. Y. D., Jimison, Z., Richard, D. ve Chuan, C. H. (2015). Effect of listening to music as a function of driving complexity: a simulator study on the differing effects of music on different driving tasks. In Proceedings of the 8th International Driving Symposium on Human Factors in Driver Assessment, Training, and Vehicle Design, 254-260. doi:10.17077/drivingassessment.1580

Whiteside, S. P. ve Lynam, D. R. (2001). The five factor model and impulsivity: Using a structural model of personality to understand impulsivity. Personality and Individual Differences, 30(4), 669-689.

Wickens, C. M., Toplak, M. E. ve Wiesenthal, D. L. (2008). Cognitive failures as predictors of driving errors, lapses, and violations. Accident Analysis and Prevention, 40(3), 1223-1233.

Wiesenthal, D. L., Hennessy, D. A. ve Totten, B. (2000). The Influence of Music on Driver Stress 1. Journal of Applied Social Psychology, 30(8), 1709-1719.

Zimmermann, G. (2010). Risk perception, emotion regulation and impulsivity as predictors of risk behaviours among adolescents in Switzerland. Journal of Youth Studies, 13(1), 83-99.

Zuckerman, M. (1994). Behavioral Expressions and Biosocial Bases of Sensation Seeking. Cambridge University Press, New York. 